\title{
SUSTAINABILITY IN EAST-NORDIC PROCEDURAL LAW ${ }^{1}{ }^{2}$
}

\section{SUSTENTABILIDADE NO DIREITO PROCESSUAL DO LESTE NÓRDICO}

Laura Ervo

Professor of law at University of Örebro, Sweden, PhD. E-mail: laura.ervo@oru.se

\begin{abstract}
This article studies the courts' procedures in the East-Nordic and discusses the link to several aspects of sustainability. In this chapter, the concepts and dimensions of sustainability are discussed first. This is followed by a description of the way in which sustainability fits in with the East-Nordic theoretical context of Scandinavian realism. Before the conclusions, the contemporary procedural paradigm is discussed from a sustainability perspective.
\end{abstract}

KEYWORDS: Courts' procedures in the East-Nordic; sustainability; Scandinavian realism.

RESUMO: O presente artigo analisa os procedimentos dos Tribunais no Leste-Nórdico e discute suas conexões com diversos aspectos da sustentabilidade. Primeiramente, serão discutidos os conceitos e dimensões da sustentabilidade. Em seguida, realizar-se-á uma descrição da maneira com a qual a sustentabilidade encaixa no contexto teórico do realismo escandinavo no Leste-Nórdico. Antes das conclusões, o paradigma do processo contemporâneo é discutido a partir de uma perspectiva da sustentabilidade.

PALAVRAS-CHAVE: Procedimentos nos Tribunais do Leste-Nórdico; sustentabilidade; realismo escandinavo.

\footnotetext{
${ }^{1}$ Artigo recebido em 30/11/2021, sob dispensa de revisão.

2 Article originally published at Law and Sustainable Development. Ed. by Eleonor Kristoffersson \& Mais Qandeel. ISBN: 9789177371809. Iustus Förlag, Sweden 2021.
} 


\section{THE STATUS AND VISION OF SUSTAINABILITY}

Before the Covid-19 pandemic, sustainability was the main global talking point. The main news concerned discussions and decisions regarding sustainability. This was the case also in the East-Nordic countries, that is Sweden and Finland. Still, the current pandemic has changed the situation. Naturally, people, states and other actors in society at large will have other problems to tackle if the pandemic is not kept under control. The same applies to the media. There is no longer sufficient space or perhaps even the same need for news regarding climate change and sustainability compared to the pandemic. However, despite this global Covid-19 crisis, the climate and sustainability will have been able to maintain their "market value" as one of the most important topics as soon as this global crisis gives way to other news too. It is now clear that sustainability seems to have survived a global crisis. There seems to be a need to promote sustainability even in the future when the pandemic - hopefully - will just be a thing of the past and when life reverts to normal again.

Therefore, there are good grounds to claim that sustainability is currently one of the most important goals also in the East-Nordic societies. If this trend and these developments continue to evolve as strongly in the future, it is possible that sustainability will become the phenomenon that shapes the East-Nordic legal culture in a rather radical way. It is the case that it lies in the mentality and culture of the East-Nordic region to follow norms and standards very carefully. There is a very strong sense of duty in the East-Nordic countries. ${ }^{3}$

The current Covid-19 pandemic may even strengthen this development in practice. Due to the pandemic many temporary changes have been made also to court proceedings. This means that technology and different types of electronical solutions are now widely used to organize court sessions and to otherwise contact courts and other authorities. This leads to sustainability put into practice when those involved do not need to travel to the courts. It saves resources, not only natural resources but also time and human energy. Some of these changes will remain also after the pandemic because they have been found to be practical. That is why it is held that court proceedings will become more sustainable in the future as far as these practicalities are concerned. ${ }^{4}$

\footnotetext{
${ }^{3}$ Ervo (2015)

${ }^{4}$ Ervo (2021)
} 
Still, sustainability is not only about combating climate change and protecting the environment. It is common knowledge that sustainability consists of environmental, economic, social as well as cultural sustainability ${ }^{5}$ where environmental sustainability is the best known and traditionally oldest ingredient of sustainable development. More recently also the other aspects have been in focus, and the discussion for instance on the scope of social and cultural sustainability have received more attention.

The Covid-19 pandemic together with the current AI and digitalization trend -which is not only an East-Nordic trend but also a global one - belong to the environmental part of sustainability which in this case is linked to economic sustainability too. It is something which definitely also concerns courts and court proceedings. It makes a difference whether court proceedings are digital and held remotely or physically face to face. In addition, social and cultural sustainability are also important factors as far as the substance of court procedures is concerned. For example, fairness - covering both normative and perceived fairness - as well as active participation, communication, and interaction are all essential factors of social sustainability. The same applies to therapeutic jurisprudence. The legal culture and court culture as its subcategory are - of course - included in cultural sustainability which is therefore also linked to court proceedings.

A fair trial, perceived fairness, active participation, communication, and interaction during court proceedings have been in focus since the 1990s especially as regards Finnish procedural law research and academic discussions. Normative fairness and Article 6 of the European Convention on Human Rights have shaped the case-law and there are many precedents with regard to fair trials in Finland. In Sweden, that discussion has not been as active but as a matter of fact, the same convention is valid and normative requirements do exist. Instead, in Sweden, the discussion has focused on therapeutic jurisprudence and the ultimate functions of proceedings.

Court procedures are therefore linked to several aspects of sustainability. In this article, the concepts and dimensions of sustainability are discussed first. This is followed by a description of the way in which sustainability fits in with the East-Nordic theoretical context of Scandinavian realism. Before the conclusions, the contemporary procedural paradigm is discussed from a sustainability perspective.

\footnotetext{
${ }^{5}$ https://www.ym.fi/fi-fi/ymparisto/kestava_kehitys/mita_on_kestava_kehitys, visited 2021-07-01.
} 


\section{CONCEPTS AND DEFINITIONS}

Two main concepts of sustainability are applied in a legal context. They are sustainability-functionalism and sustainability-factualism. Often it is said that only the latter, sustainability-factualism has an impact in a legal context. Sustainability-functionalism refers to those procedures whose purpose and task is to preserve existing resources. Therefore, legal procedures are often seen as non-preserving procedures. For instance, Linna is of the opinion that a procedure as such does not produce functional sustainability because results depend on substantive law. Thus, according to her, procedure is based on sustainability-factualism, where a party may choose a type of procedural tool that allows sustainable solutions. Other types of procedures may also save resources even if preserving resources is not their principal purpose. In such cases, sustainability is a by-product. ${ }^{6}$ Linna seems mainly to concentrate on the traditional scope of environmental sustainability. Additionally, she has a pragmatic point of view when stressing concrete outcomes which must be sustainable or even preferably if they also promote sustainability in the future like certain court cases connected with environmental law may do.

This view is too narrow. The concepts of sustainability need to be linked to the purpose of a legal procedure which is to apply material law in situations of dispute or violation. There is no legal procedure for the legal procedure alone, but procedures exist to serve the application of material law. Still, material law does not exist in dispute or violation situations without the help of procedural law, or to be more concise: it does exist, but practical effects are not possible. Since legal procedures, and therefore procedural law, are essential for the application of material law and it is impossible to distinguish their roles, legal procedures also produce functional sustainability whenever material law does so. ${ }^{7}$ Therefore, they produce functional sustainability together. For instance, environmental cases clearly constitute such a situation.

There might also be functional sustainability whenever procedural tools are seen from practical, sustainable perspectives. Process principles, such as the principle of the

\footnotetext{
${ }^{6}$ Linna (2018), p. 658.

7 Ervo (2020), pp. 75-76.
} 
appropriateness of the process (cost, time, certainty), which will speed up dispute resolution and diminish the increase in costs, also result in sustainability (covering both environmental and economic sustainability). The same applies to the principle of certainty. Sustainability is not only about time and costs, but also about sustainable content, which may be deemed certain and fulfil the requirements of fairness and quality. Technical solutions help bring about sustainability in practice, examples being remote witness attendance and an electronic document service. These are examples of real and pragmatic sustainability at its best. Therefore, the borderline between functional and factual sustainability in proceedings is changeable. The sustainable procedure may fulfil the demands of functional sustainability as such and not only factual sustainability as a by-product, especially when one of the main aims of the proceedings is to organize matters in a sustainable way. ${ }^{8}$

In a later article, Linna has also changed her perspective. She writes about procedures that produce sustainability and procedures where it is a by-product. She now seems to have softened the dichotomy of functional / factual sustainability. She also mentions internal and external sustainability where internal sustainability refers to outcomes like functional sustainability and external sustainability refers to sustainable procedures as such. ${ }^{9}$

As a conclusion, I see procedures covering both perspectives depending on the case. A procedure may be organized in a sustainable way when it achieves functional or internal sustainability. Additionally, a procedure may promote sustainability through court decisions and judgments. Depending on the matter at hand, they may promote sustainability as such. However, in that case the substance naturally emanates from material law.

In addition, legal procedures may also promote and produce sustainability through their procedural scope. For instance, when a procedure has been fair and perceived as fair, and participation, interaction, and communication have been fair and successful too, the procedure has implemented and produced social sustainability. All that affects and belongs to the legal culture and especially its subclass, court culture. In this way, it is a matter of cultural sustainability too. As such, sustainability matters in both court procedures and in procedural law. Legal procedures touch upon sustainability in several and various ways.

\footnotetext{
${ }^{8}$ Ervo (2020), pp. 75-76.

${ }^{9}$ Linna (2020).
} 
The same applies to procedural practice outside courts. According to empirical studies, it is common that lawyers consider matters of sustainability when advising their clients and choosing how to solve a dispute. However, they do not always know exactly what sustainability actually means and includes. It is also normal that the aims and choices that are nowadays called sustainable correspond with the traditional objectives of the work of a lawyer. How modern is the concept of sustainability really? Many of its ingredients have been complied with for decades but earlier it was called economy or reasonableness. Still, the difference is that earlier the reasons for "sustainable" choices were egoistic and individual whereas nowadays sustainability refers to global common wealth and benefits to society instead of directly egoistic gains. ${ }^{10}$

\section{DIMENSIONS OF SUSTAINABLE JUSTICE}

Justice is the most important instrument for the promotion of sustainable development in procedural law. Based on the Sustainable Development Goals (SDGs), also known as the Global Goals, which were adopted by all United Nations Member States in 2015, peace, justice and strong institutions are included as aims in sustainability. Goal number 16 includes different aspects of justice like peace, fairness, and good governance (thus translated into Finnish). In Sweden, the same Goal, number 16, has been expressed in words such as peaceful and inclusive communities. Justice, which has not been translated literally in all translations, is the common main component which is subsequently implemented and is reflected in the components mentioned above.

The components on which justice is formed, seem to be nationally and culturally coloured. In Sweden, inclusive and peaceful communities are emphasized in the translation. The first ingredient, peace, is almost identical in all languages studied but in Swedish it is not only about peace as such, it has been put into the context of society and that society should be not only peaceful but also inclusive. This approach is very context-based and typically Swedish, where everyone's attendance/presence is culturally and socially a very typical way of doing things and a widely accepted goal in Sweden. This translation reflects Swedish social values in understanding justice well. Whereas in Finland, the scope is more normative and,

\footnotetext{
${ }^{10}$ De Savornin Lohman (2011), pp. 3 - 4.
} 
for example, fairness and good governance have been separated into two different components in this context. This translation into Finnish corresponds with the contemporary discussions in Finland, where a fair trial and good governance as granted in international conventions have widely modified the procedural law since the 1990s and have been the most discussed topic in procedural literature over the past few decades. ${ }^{11}$ It is interesting how the cultural context may be reflected in the choice of words and in the way matters are expressed. How to approach sustainability seems to be partly a cultural question.

In all cases, this East-Nordic aspect of sustainability, namely peace, fairness, and good governance as well as peaceful and inclusive communities are closely connected with proceedings. Procedures and ways of solving disputes are needed to achieve peace and to keep society peaceful. Justice, fairness, and good governance are as such legal - and mainly procedural law - terms. To meet goal number 16 in the East-Nordic style, procedures that are based on justice and fairness are needed, including good governance in administrative bodies. In addition, all this should be organized in a way which fulfils the goal of inclusive communities.

Despite the different details in translations, justice is the starting point and the common main component which will lead to sustainability in procedural law and practice. Since justice may be understood in many ways and different components might be included based on an actor's own values and rankings, it is important to discuss the dimensions which justice may have in this context of sustainability.

Justice in the context of sustainability includes the three following dimensions:

1. Justice among humans of different generations ("intergenerational" justice);

2. Justice among different humans of the same generation ("intragenerational" justice); and

3. Justice between humans and the natural environment ("physio-centric ethics"). ${ }^{12}$

Legal procedures are mainly linked to the inter or intragenerational aspect of justice but also justice between humans and the natural environment may be relevant particularly in environmental cases if the natural environment - despite not being a party in a case - is seen to be protected by justice. Legal procedures and for instance dispute resolution at its best, are

\footnotetext{
${ }^{11}$ Heinonen - Lavapuro (2012).

${ }^{12}$ Linna (2018), p. 656. See also Stumpf, Becker and Sievers-Glotzbach (2015), pp. 7439-7450.
} 
good examples of intra or intergenerational justice among different humans of the same or different generations. Another question is whether legal procedures lead to justice in all cases. Still, justice as an aim is traditionally linked to dispute resolution and legal procedures. It is normally ranked at the top of the values and principles affecting legal procedures in general. Therefore, there is good reason to argue that legal procedures may promote sustainability as such as a practical tool with which to realize social and cultural sustainability goals.

Still, some scholars take a different perspective. According to them, conflicts, and dispute resolution as such, may be seen as harmful from a sustainability point of view. On the one hand, it is naturally something negative, but on the other, it is not avoidable in human societies only in a utopia. If we first accept this point of departure, that there is and always will be disputes and violations of law in human societies and therefore that legal procedures are a must, we can thereafter consider the kinds of legal procedures that best correspond and promote sustainability. At the system level, it is possible to argue that legal procedures do not lead to the achievement of sustainability goals like De Savornin Lohman does ${ }^{13}$.

According to De Savornin Lohman, the following systems and power interventions are favourable to the environment: ${ }^{14}$

- $\quad$ Promotion of co-operation and improvement of relationships

- $\quad$ Promotion of mutual respect

- $\quad$ Strengthening of the sense of responsibility

- $\quad$ Keeping problems in context

- $\quad$ Finding resolutions to causes of problems

- $\quad$ Encouragement for the parties

- $\quad$ Strengthening of the morality of the parties and taking that to a higher level

- $\quad$ Focusing on the positive aspects

- $\quad$ A future oriented focus

- $\quad$ Focus on opportunities and new perspectives

- Focus on reintegration and rehabilitation

\footnotetext{
${ }^{13}$ De Savornin Lohman (2011), p. 5.

${ }^{14}$ De Savornin Lohman (2011), p. 5.
} 
Whereas the following systems and power interventions are unfavourable: ${ }^{15}$

- $\quad$ Causing harm to mutual relationships

- Conflict escalation or promotion (sometimes contradiction is needed to provide clarity)

Removing material interests from the connection between material and immaterial interests that they form a part of (e.g.: juridification of a conflict to become a legal dispute)

- $\quad$ Monitoring, assessment, judgment condemnation, retributive punishment

- Imposing a solution (such as court decisions) that are not connected to the ecosystem or that does not secure the ecosystem

- Imposing or pressing solutions (what could for instance happen during a Hearing----after----Defense)

- $\quad$ Materialist strengthening

- $\quad$ Focusing attention on negative aspects or on what went wrong (except where this is necessary as a part of a forward-looking perspective, such as the strengthening of a sense of responsibility and mutual respect, creating good relationships, rehabilitation, and reintegration)

- $\quad$ Focusing on the past

Lohman's report is based on different perspectives on legal procedures and dispute resolution compared with mine. At the pragmatic or internal level, which I find the most important, it is possible to research these procedural tools and develop them to be as sustainable as possible. Therefore, in individual procedures, sustainability is definitely included. In addition, it should also be mentioned that Lohman's report was published before the UN's Agenda 2030. Therefore, the points of view and terms used differ and the cited lists cannot be fully compared with the current discussion on sustainability, with justice as its component.

\section{SUSTAINABILITY IN THE CONTEXT OF SCANDINAVIAN REALISM}

\footnotetext{
${ }^{15}$ De Savornin Lohman (2011), p. 5.
} 
From the historical perspective, the main phenomenon shaping East-Nordic legal culture is Scandinavian realism, which was the Nordic - in particular the Swedish - reply to the critique of legal formalism. ${ }^{16}$ Therefore, it is interesting to see how sustainability corresponds with Scandinavian realism and whether sustainability can be a success in EastNordic procedural law also as far as legal theory is concerned.

Scandinavian legal realists abandoned natural law theories as metaphysical and legal positivism as unscientific. Jurisprudence should instead be understood as social theory and legal policy as social technology. ${ }^{17}$ The perspective and objective are pragmatic. The main point of Scandinavian realism is to deny the possibility of a science of justice or values. ${ }^{18}$ It was the role of the sociology of law to describe the relationship between law and society, on the one hand, and the "cultural values" of law on the other. Dogmatic scholarship, a normative science, could subsequently decide between the alternatives thus brought to the fore. ${ }^{19}$ It was philosophy and law needs that were to be forced to serve social needs. Alf Ross stressed this perspective and wanted to see law as social policy. ${ }^{20}$ Ross claimed that the task of a legal scientist is to function as a "rational technician", assisting the political decision-makers by elaborating on the most appropriate means by which a given end can be realized. ${ }^{21}$

From that perspective, sustainability as a social demand and policy fits in very well with this theoretical background. Sustainability is important because it is currently an important policy in society and there is a need to adjust real activities in society according to the demands of sustainability. It is important to survive and to save the planet and the natural environment for future generations. From this perspective, the law can be seen as a tool for the realization of this aim.

Traditionally, Nordic law is lay-dominated. That is why the pragmatist, policyoriented solutions promoted by legal realism, fell onto fertile ground in Sweden. There, law had never lost its connection with the everyday lives of normal people. Swedish legal professionals had never managed to monopolize their language and culture in the way their

\footnotetext{
${ }^{16}$ Sreeparvathy (2011).

${ }^{17}$ Pihlajamäki (2004), p. 472 - 474 and Sreeparvathy (2011), pp. 15-16.

${ }^{18}$ Pihlajamäki (2004), p. 471 and Sreeparvathy (2011), pp. 13-14.

${ }^{19}$ Pihlajamäki (2004), p. 474.

${ }^{20}$ Pihlajamäki (2004), p. 471 and Sreeparvathy (2011), pp. 13-14.

${ }^{21}$ Ross (2013), p. 466 and Strang (2009), p. 74.
} 
colleagues in the more southern parts of Europe had been able to do. ${ }^{22}$ Also from this perspective, it is not problematic to use legislation and case-law to achieve sustainability in the East-Nordic legal culture whenever societal needs so demand. Law is not something which stands alone but its validity relates to social needs and people's values. It is important that the law corresponds with the practical matters that are important in society. In other words, a legal solution must work in practice and correspond to the current values in society so that the law can be complied with without moral dilemma. If not, the law can ultimately be seen as not valid. ${ }^{23}$ In this sense, Nordic law has been more about the experience than the logic and Nordic jurists are, by tradition, pragmatists. ${ }^{24}$

It was typical of Scandinavian realism to see law from a perspective where law really could change society. ${ }^{25}$ The aim of sustainability and the global goals which describe its scope are pragmatic and instrumental. They can be seen as concrete tools for the realization of sustainability goals as such. The objective is to find practical solutions to promote sustainability and to shape its various aspects. All that is appreciated in East-Nordic law and this type of approach fits well into the background of Scandinavian realism as well. Therefore, from the legal theory perspective, there is nothing that suggests that sustainability will not significantly shape East-Nordic law even today.

\section{FAIRNESS AND SUSTAINABILITY}

Global goal $\mathrm{nr} 16$ is all about peace, justice, and strong institutions. As explained above, it is translated into Swedish with the words peaceful and inclusive societies ("fredliga och inkluderande samhällen"). In Finland, it reads peace, fairness, and good governance ("rauha, oikeudenmukaisuus ja hyvä hallinto"). These translations are not literal but reflect national values and preferences. Especially, the way "justice" has been translated is significant. "Justice" is a term which is strongly connected with morals and values. It is for everyone to decide what they perceive as justice. In Sweden, inclusive societies are the main component. This means it is individuals participating actively and freely that form justice,

\footnotetext{
22 Pihlajamäki (2004), p. 486.

${ }^{23}$ Ervo (1996), p. 35.

${ }^{24}$ Arg. Pihlajamäki (2004), p. 487.

${ }^{25}$ Malminen (2010), p. 319.
} 
while in Finland it is fairness. Both translations are understandable from the domestic, social point of view; they reflect the current values in both countries. ${ }^{26}$

When applying this to court proceedings, the contemporary court culture in EastNordic countries is based on communication and interaction between the parties and the judge. For instance, in civil litigation it is typical that the legislator has partly delegated its powers to those involved and the judge enjoys a great deal of discretionary power to find the best and the most reasonable solution for the case in co-operation with the parties. For instance, one of the most important duties of a judge is to try to find a friendly settlement in a case during the preparatory stage. At the same time, the parties may choose - more often now than earlier the most suitable type of proceedings to resolve their conflict ${ }^{27}$ as well as to some extent even the substantive basis for the final decision. Procedural and substantive party autonomy plays a significant role. There has been a radical change from the adjudication, ideals of material law and a substantively correct judgment towards the ideal of negotiated law and pragmatically acceptable compromise. ${ }^{28}$ There are similar trends also in criminal proceedings even if these are naturally a different type of context which also has its limits. ${ }^{29}$

Currently, the most important function in the adjudication is that the contextual decisions, which the parties are satisfied with, are produced through fair proceedings. Two main goals exist, namely procedural fairness and substantial satisfaction. There has even been a change from formal justice towards a perceived procedural justice and from judicial power towards a court service, which means that it is not enough to follow normative fairness, but the parties should additionally feel that the procedure was pleasant and even this kind of perceived fairness is nowadays a significant factor in due procedure. The adjudication can now be called court service. ${ }^{30}$ In this kind of procedure, the judge is seen more as a helper of the parties than the actor who is using his/her public power to make final decisions. ${ }^{31}$

\footnotetext{
${ }^{26}$ Ervo (2015), p. 149.

${ }^{27}$ Today, the main function of civil proceedings is conflict resolution instead of traditional dispute resolution (sanction mechanism) or legal protection.

${ }^{28}$ Ervasti (2004), p. 168, Haavisto (2002), p. 20, Laukkanen (1995), p. 214, Takala (1998), pp. 3-5, Tala (2002), pp. 21-23, Tyler (1990), p. 94 and Virolainen - Martikainen (2003), p. 5.

${ }^{29}$ Ervo (2021a), pp. 109 - 111.

${ }^{30}$ Ervasti (2004), p. 168, Haavisto (2002), p. 20, Laukkanen (1995), p. 214, Takala (1998), pp. 3-5, Tala (2002), pp. 21-23, Tyler (1990) p. 94 and Virolainen - Martikainen (2003), p. 5.

${ }^{31}$ Ervo (2013), pp. $52-53$.
} 
In Sweden, there has also been a broad discussion on the ultimate functions of proceedings. Conflict resolution has often been seen as the most important function of civil proceedings (in particular) and with this development the perspective has changed from the external towards the internal and from a retrospective towards prospective point of view. ${ }^{32}$ With this change, the parties are nowadays much more at the centre of the proceedings than earlier.

The Swedish Ministry of Justice commissioned already in 2008 broad research concerning the trust that people hold in the courts. According to that report, there are several factors which are important as regards our trust and confidence in the courts. The list is as follows: the accessibility of the courts and the court staff for the parties and people giving evidence, the courts' reception of the parties and people giving evidence, the processing times of the courts, the transparency of the courts' decision-making processes, the wording of judgments and decisions, the way in which the activities of the courts are portrayed by the media, the knowledge of the general public about what goes on in the courts and finally the conduct of judges. ${ }^{33}$ All these elements refer to the new role of the judges where action is based more on social than legal skills. The public is looking for help and service. They are no longer satisfied with the distant and formal judges whose authority is based on the law and the institution as such. They are no longer looking for authoritative and final decisions made by the powers that be. They are seeking co-operative skills to help solve a conflict and then to move on in their lives. ${ }^{34}$ This change means also changes to democracy.

All that fits in neatly with sustainability. This is because sustainability in proceedings primarily means social sustainability and justice; the change in paradigm explained above corresponds with that goal. Goal nr 16, especially in Finland, puts the emphasis on fairness whereas in Sweden the emphasis is on co-operation and equal participation for all (inclusive societies). If we compare these approaches, we see that the contemporary procedural paradigms in both East-Nordic countries are already enabling the countries to achieve goal nr 16 very well.

\footnotetext{
${ }^{32}$ Ervasti (2002), pp. 56 - 62, Leppänen (1998), pp. 32 - 41, Lindell (2003), pp. 82 - 101, Lindblom (2000), pp. $46-58$ and Virolainen (1995), pp. $80-89$.

${ }^{33}$ SOU 2008:106, p. 26.

${ }^{34}$ Ervasti (2002), pp. 56 - 62, Leppänen (1998), pp. 32 - 41, Lindell (2003), pp. 82 - 101, Lindblom (2000), pp. $46-58$ and Virolainen (1995), pp. $80-89$.
} 


\section{THERAPEUTIC JUSTICE AND THE ACHIEVEMENT OF THE SUSTAINABILITY GOALS}

Especially in Sweden, there has been a discussion on therapeutic justice and how it affects court proceedings. According to therapeutic jurisprudence, there are always social effects involved in legal matters. For instance, law and adjudication do not only reflect and govern the economy, politics, and moral issues, they also reflect and influence the wellbeing of the citizens. In therapeutic jurisprudence, it is stressed that it is not only a question of private interests and the private wellbeing of individuals that is at stake, but that, especially in the long run, the ignorance of the aforementioned social elements and social needs in law and in proceedings may lead to negative or harmful consequences for the whole of society (e.g., a legitimacy crisis or revolutionary behaviour). Thus, there is clearly also a public interest in adopting a more therapeutic jurisprudence. ${ }^{35}$

The latter aspect is extremely important and true. Social aspects can be linked to therapy, but their connection with wider private and public interests needs to be understood. Fairness and trust in courts and the legitimacy of the whole system are issues which also relate to the social aspects of proceedings. It is important to understand that these "therapeutic" values which can be categorized as soft values affect the whole system and its legitimacy. That is why they are at the same time also extremely hard values.

While traditional proceedings are seen as vertical and focusing on dispute resolution, the transformed therapeutic proceedings are seen as horizontal, problem-solving, and dispute avoiding. The traditional way of handling conflicts is formal, adversarial, claim-oriented, and rights-based, whereas more modern proceedings are informal, collaborative, people-oriented and interest or needs-based. In traditional procedures, the application and interpretation of the law are important while in more therapeutic procedures the application of human behaviour research is seen as a key component. There are also differences in the judge's role. Traditionally, the judge has been seen as an arbitrator, whereas in the new form s/he acts more like a peacemaker or a coach. The orientation is now forward-looking instead of backwardlooking and the outcome should also be therapeutic and not only legal. The traditional procedure may be dispassionate, impersonal, and formal (with an isolated judge making

\footnotetext{
${ }^{35}$ Diesen (2011), pp. 151 - 155 and Winick (1997), p. 648.
} 
decisions), but the more modern procedure is open and personal as it is based on a team approach and co-operation when decisions are made or investigations are conducted. ${ }^{36}$ The change in the procedural paradigm as described in section 5 above, corresponds well with the scope of therapeutic justice. The current paradigm seems to realize the demands of therapeutic justice very well. All this fits in extremely well with social sustainability and with justice as its key component, in particular if justice is understood to mean that the perceived parts are appreciated and valued as significant.

Therapeutic jurisprudence has been criticized for being paternalistic. Showing empathy and avoiding confrontation is something which therapeutic jurisprudence may bring into focus in more modern proceedings. It is something which is needed in well-functioning human relationships. Therapeutic jurisprudence is not an alternative but a supplement to the traditional judicial process. Its extra value is in conflict resolution and rehabilitation. It is possible to achieve both aims more easily and in a much better way through therapeutic jurisprudence compared with traditional proceedings where the named objectives remain the core. $^{37}$

From the sustainability perspective, therapeutic jurisprudence is rather interesting. It is very close to social sustainability and global goal nr 16 with its fairness and inclusive societies. If sustainability is able to maintain its current top position as one of the most important objectives in society, the wider discussion on the significance of therapeutic jurisprudence must be raised. The next step to achieve more modern court proceedings is to place a greater focus on their real contents like communication, use of language, the behaviour of the parties, interaction. transparency, and so on. To develop those parts towards sustainable procedures especially social sustainability - bearing justice, fairness, and inclusive societies in mind - the social and pragmatic aspect of procedural law needs to a greater focus. Therefore, there might be a second coming for Scandinavian realism in the context of sustainability in the proceedings. Similarly, the therapeutic jurisprudence may gain much greater significance as soon as these mental values of legal procedures are better recognized. Sustainability is a promising context for this kind of development.

\footnotetext{
${ }^{36}$ Diesen (2011) p. 153.

${ }^{37}$ See Diesen (2011), pp. 157- 160.
} 


\section{CONCLUSIONS}

From the theoretical point of view, it is confusing how sustainability is theoretically placed in procedural law. Dissenting opinions of main concepts and components and different ways of thinking when considering sustainability in dispute resolution and other types of legal proceedings as such cause frustration. More research and academic discussions are needed to place sustainability in the theory of procedural law. Currently, the overall picture is fragmented and incomplete. Scholars have just started to approach the topic but are not yet fully there.

In procedural real life, like in the courts or in other forms of dispute or conflict resolution, the situation is better. Even if the discussions on sustainability in procedures are lacking, in practice different types of legal procedures and conflict or dispute resolution types realize the demands of sustainability quite well. For instance, group actions ${ }^{38}$, mediation, fair trials, therapeutic jurisprudence and so on promote social and even economic sustainability better than traditional court proceedings do. Among the traditional court proceedings, digital solutions are becoming increasingly common which promotes environmental sustainability and as long as they save time and costs, they affect economic sustainability positively at the same time.

Sustainability is rather important as far as East-Nordic procedural law in terms of content is concerned. Already Scandinavian realism can be seen as a theoretical frame which provides good starting points for the realization of sustainability goals in procedural law too. Additionally, the recent changes in the East-Nordic procedural paradigm can be seen as a sustainable reflection. Still, sustainability is not often mentioned in the literature as yet.

The reason for this clear connection and correspondence with sustainability and the content of current East-Nordic procedural law lies in pragmatism and Scandinavian realism. The link between the law and societal needs has always been strong in the East-Scandinavian countries. In addition, in order for it to be valid, the law needs to function well in practice and correspond with the main current values in society. Therefore, it is natural that if sustainability is found to be one important goal and value in society, it will affect the law which will in time be modified and move towards sustainability.

\footnotetext{
${ }^{38}$ Ervo (2021b), p. 194.
} 


\section{REFERENCES:}

De Savornin Lohman 2011

De Sarvornin Lohman Alexander, Working Document on Sustainable Justice for the Expert Meeting on Sustainable justice organized by the Montaigne Center for Justice and conflict resolution at the University of Utrecht, December 2, 2011, https://papers.ssrn.com/sol3/papers.cfm?abstract_id=2210027m, visited 2021-07-01.

Diesen 2011

Diesen, Christian, Terapeutisk juridic, Liber 2011.

Ervasti 2002

Ervasti, Kaijus, Lainkäytön funktiot. Lakimies, 2002, pp. 47-72.

Ervasti 2004

Ervasti, Kaijus, Käräjäoikeuksien sovintomenettely. Empiirinen tutkimus sovinnon edistämisestä riitaprosessissa. Helsinki: Oikeuspoliittinen tutkimuslaitos 2004.

Ervo 1996

Ervo, Laura, Ylimmät prosessiperiaatteet - oikeudenmukaisen oikeudenkäynnin osatekijät. Lakimiesliiton Kustannus 1996.

Ervo 2013

Changing Civil Proceedings: Court Service or State Economy? In: Recent Trends in Economy and Efficiency of Civil Procedure, Vilnius: Vilnius University Press, 2013, pp. 51-71.

Ervo 2015

Ervo, Laura, Comparative Analysis Between East-Scandinavian countries In: Scandinavian Studies in Law, Stockholm: Stockholm Institute for Scandinavian Law, 2015, pp. 135152.

Ervo 2020

Ervo, Laura, The Finnish Way of Understanding Procedural Autonomy: A Practical Approach to Implementing EU Civil Procedural Law, In Procedural Autonomy Across Europe. Ed. by Anna Nylund and Bart Krans. Intersentia: pp. 57-80.

Ervo 2021 
Ervo, Laura, Pandemic and Digitalization - The Situation in the Finnish Lower Courts In: Civil Courts Coping with Covid-19 / [ed] Bart Krans, Anna Nylund, The Hague: Eleven International Publishing, 2021, pp. 73-82.

Ervo 2021a

Ervo, Laura, Straffprocessens funktioner. Festschrift for Bengt Lindell, Iustus Förlag 2021. Forthcoming.

Ervo 2021b

Ervo, Laura,

Group Actions in East-Nordic Legal Culture, In: Class Actions in Europe: Holy Grail or a Wrong Trail? / [ed] Alan Uzelac \& Stefaan Voet, Springer, 2021, pp. 177-199.

Haavisto 2002

Haavisto, Vaula, Court Work in Transition. An Activity- theoretical Study of Changing Work Practices in a Finnish District Court. Helsinki: University of Helsinki 2002.

Heinonen - Lavapuro 2012

Heinonen, Tuuli, - Lavapuro, Juha, Oikeuskulttuurin eurooppalaistuminen: ihmisoikeuksien murroksesta kansainväliseen vuorovaikutukseen. Suomalainen Lakimiesyhdistys 2012.

Laukkanen 1995

Laukkanen, Sakari, Tuomarin rooli. Helsinki: Suomalainen Lakimiesyhdistys 1995.

Leppänen 1998

Leppänen, Tatu, Riita-asiain valmistelu todistusaineiston osalta. Helsinki: Suomalainen Lakimiesyhdistys, 1998.

Lindblom 2000

Lindblom, Per Henrik 2000. Processens funktioner - en resa i gränslandet. In Progressiv process. Spridda uppsatser om domstolsprocessen och samhällsutveclingen. Uppsala: Iustus, 2000, pp. $41-85$.

Lindell 2003

Lindell, Bengt, Civilprocessen. Andra upplagan, Uppsala: Iustus 2003.

Linna 2018

Linna, Tuula, Sustainability ja prosessit - kestävää siviiliprosessioikeutta? Lakimies 2018/6: pp. 651-676. 
Linna 2020

Linna, Tuula, Business Sustainability and Insolvency Proceedings-The EU Perspective. J Sustain Res. 2020;2(2):e200019. https://doi.org/10.20900/jsr20200019, visited 202107-01.

Malminen 2010

Malminen, Toni, Upsalan koulukunnan jalanjäljillä. Oikeus 2010/39: pp. 318-324.

Pihlajamäki 2004

Pihlajamäki, Heikki, Against Metaphysics in Law: The Historical Background of American and Scandinavian is Compared. The American Journal of Comparative Law, Vol. 52, No. 2/2004, Oxford University Press, pp. 469-487.

Ross 2013

Ross, Alf, Om ret og retfaerdighed. Hans Reitzels Forlag, Köpenhamn 2013.

SOU 2008:106. Ökat förtroende för domstolarna - strategier och förslag. Betänkande av Förtroendeutredningen. Statens offentliga utredningar. Available on the web: http://www.regeringen.se/content/1/c6/11/67/31/b9652d60.pdf.

Sreeparvathy (2011)

Sreeparvathy G, Scandinavian Realists. Available at

SSRN: https://ssrn.com/abstract=1829163 or http://dx.doi.org/10.2139/ssrn.1829163, visited 2021-07-01.

Stumpf - Baumgärtner - Becker - Sievers-Glotzbach 2015

Stumpf, Klara Helene - Baumgärtner, Stefan - Becker, Christian U., Sievers-Glotzbach, Stefanie, The Justice Dimension of Sustainability: A Systematic and General Conceptual Framework: Sustainability 7: pp. 7438-7472. Avaliable on the web: https://papers.ssrn.com/sol3/papers.cfm?abstract_id=2579346, visited 2021-07-01.

Takala 1998

Takala, Jukka-Pekka, Moraalitunteet rikosten sovittelussa. Helsinki: Oikeuspoliittinen tutkimuslaitos 1998.

Tala 2002

Tala, Jyrki, Luottamus tuomioistuimiin - mitä se on ja tarvitaanko sitä lisää? Lakimies 2002, pp. $3-33$.

Tyler 1990 
Tyler, T. R., Why people obey the law? New Haven, London: Yale University Press, 1990.

Winick 1997

Winick, Bruce J., The jurisprudence of therapeutic jurisprudence. Psychology, Public Policy, and Law 1997, pp. 184-206.

Virolainen 1995

Virolainen, Jyrki, Lainkäyttö. Helsinki: Lakimiesliiton Kustannus 1995.

Virolainen - Martikainen 2003

Virolainen, Jyrki - Martikainen, Petri, Pro et contra: tuomion perustelemisen keskeisiä kysymyksiä. Helsinki:Talentum 2003.

\section{Webpages:}

https://um.fi/agenda-2030-sustainable-development-goals, visited 2021-07-01.

https://www.regeringen.se/regeringens-politik/globala-malen-och-agenda-2030/agenda2030-for-hallbar-utveckling/, visited 2021-07-01.

https://www.ykliitto.fi/yk-teemat/kestava-kehitys/kestavan-kehityksen-tavoitteet, visited 2021-07-01.

https://www.ym.fi/fi-fi/ymparisto/kestava_kehitys/mita_on_kestava_kehitys, visited 202107-01. 